\title{
PLANNING SHORT-STAY 'WEEKEND BREAKS' BASED ON THE CULTURAL, NATURAL AND SOCIAL RESOURCES OF THE SMALL TOWN
}

\author{
ANNA OSTROWSKA-TRYZNO, ${ }^{1}$ ANNA PAWLIKOWSKA-PIECHOTKA ${ }^{2}$
}

\author{
Joseph Pilsudski Academy of Physical Education Warsaw, POLAND \\ 1 e-mail: anna.tryzno@gmail.com \\ 2 e-mail: anna.piechotka@gmail.com
}

KEYWORDS

ABSTRACT cultural tourism, weekend - breaks, planning sustainable tourism, small town, regional promotion

The paper examines the way that place with a specific identity and cultural atmosphere could be used as the promotion of the site and creation the popular short-stay tourist destination. The authors briefly explained the theoretical background, concepts, marketing methodologies and effects of coordination between local government actions and tourism industry promotion. On the example of case study in Podkowa Leśna, it illustrates different activities and different issues involved, identified important determinants. Emphasizing a smart, sustainable approach, it shows how cultural tourism and culture events could be used to promote a town successfully. It shows how the local authority's policy, the private - public cooperation, the NGOs involvement, institutional structures and volunteer's enthusiasm could create a high standard of cultural offer and tourist friendly host site. It also shows how, on the example of garden - city Podkowa Leśna, an effective management and innovative strategy could provide long term success based on cultural and social resources. In their final conclusion remarks the authors examine the relationship of cultural events and tourism growths (short-stay, 'weekend break' visits). Cultural heritage, organized sport and cultural events together with the natural values are identified as the vital determinants for the high quality experience of visitors in this destination site. The non answered question remains, if culture in future - in a broad sense of tangible and intangible forms - could be also used in the rapidly changing world for successful promotion, for sustainable development, for social and cultural harmony and economic growth. The other question to be considered in the future research study is the limit of tourism development growth at the site of high cultural and natural values, very special social atmosphere and site tradition. 


\section{Introduction}

Many scholars underline the increasing role of culture and cultural attractions in enhancing the growth of tourism industry (Dallen, 2003; Page, 2003; Sigala, 2006; Smith, 2009). Accordingly to the European Union statistics there are 200000 protected architectural monuments in the EU countries, most of high tourists interests (UNESCO, 2009). But not only tangible culture (buildings of historical meaning or museums) is important for tourist industry, intangible culture might be as well significant. The European Commission has commenced with the cooperation with the Council of Europe promotion of the European cultural heritage also in the latter aspect. For example European cycle paths, pilgrimage routes (such as "St. James Pilgrim Route"), were used to stimulate economic development, promote identity, cultural diversity and harmony. Similar activities were initiated by the Polish Tourist Organization and the Regional and Local tourist organizations in Poland (for example "Chopin 2010" cultural tourism experience).

From the part of government and local authorities the main reason for interest in cultural tourism is the need to support the development of sustainable tourism, the cultural and educational goals, which may help to protect cultural heritage visited by tourists. The other obvious reason is to increase the competitiveness of the regional tourist offer. These actions are a response to global, not only European, trends in tourism, visible both on the demand and supply side. Issues related to the many aspects of the protection of cultural heritage and development of cultural tourism were showed in many scholar publications (Dallen, 2003; Richards, 2001; Sigala, 2006; Smith, 2006).

The modern tourist, during his or her trip, is interested not only in "must - see - sights", high cultural attractions such as world famous museum (Louvre in Paris) or architectural relics (Coliseum in Rome). It was apparent in the past, that widely recognized, popular tourist attractions were at the first place the icons of global culture and these provided a focus for the mainstream of tourist activities. Today, local cultural events of rather cameral scale, charming local identity, friendly approach towards the guests are highly appreciated and seriously considered in the travel itineraries. It is example of the 4E concept of the modern tourist's motivation to travel: education, excitement, entertainment, engagement and last but not least - alternative travel experience. The 4E concept requires active involvement in the tourist journey at every stage, commitment, openness for the new experiences. There are also new forms of travelling and learning, which often derive from new technological solutions. Tourists are highly interested in participating in various events organized with the use of modern technologies such as multimedia (light-sound-image), historical productions, learn about heritage places through quests and urban games. Moreover these elements could be also successfully used for the site promotion (Gold, 1994; Hall, 1999, 2000; Inskeep, 1994; Panasiuk, 2013; Thomas, 2014; Williams, 2003).

Cultural tourism fits perfectly into these new trends in the tourism market, and a variety of cultural events could be used as a major attraction - attracting both local community members and tourists. It does not necessary mean the use of the already recognized, famous and "must see - sights". Smaller towns and remote villages could effectively attract visitors by artistic events, historical reconstructions, and educational games. These events and the presence of tourists are 
creating a new value and could promote local heritage, anthropogenic and natural values. Certainly, cultural tourism must meet a number of goals and objectives, one of which is sustainable tourism development and protection of heritage and natural resources.

Building a brand is a long - term and very complicated process, nevertheless it is connected with many other than tourism development advantages, as for example attracting potential investors (Goodall, 2014; Panasiuk, 2013). The general concept is to build a competitive brand of the site by promoting its tradition and image, culture and history. The small town or a village could be regarded as the "valuable product" shaped of tangible and intangible assets. It may include infrastructure and services, the products of local producers, as well as tradition, culture, arts, skills and customs of the inhabitants, the site uniqueness and its specific genius loci. All these elements could create a coherent, but also very complex product. For this reason, the so called "place marketing" is a challenging task. The challenge is not only the complexity of the product, but also different, sometimes difficult to define issues, related to various objectives of stakeholders involved (local authorities, private sector, public sector, local community members, institutions and organizations). Not helpful are too limited budgets for coordination of marketing activities and lack of knowledge how to do it, how to plan an effective strategy. The successful promotion poses a serious challenge for the local authorities, which is why they are looking for different ways to build the image and strengthening the recognition of the site. For example the uniqueness of the history and specific spatial and social character might be an important element of the promotion. Podkowa Leśna near Warsaw, the small town founded a hundred years ago and based on the idea of Ebenezer Howard's garden city, can be a specific chance of USP (so called "unique selling point").

The purpose of the paper is to present some outcomes of the research study undertaken to investigate the effect of cultural events in Podkowa Leśna on the sustainable tourism development and the successful region promotion.

\section{Research aim and methodology}

The aim of this study was to analyze the conditions for the development of cultural tourism in Podkowa Leśna, based on the existing cultural and natural values, organized events and very special social atmosphere of the garden city and tradition of the site. This paper presents some key issues related to the organization of the cultural events, their effects on tourism growth and the area promotion.

The material for the case study encompassed the selected cultural events organized in Podkowa Leśna by the local authority together with various governmental institutions and NGOs organizations in 2010-2015. To the deep insight analyzes authors qualified only the most important events, which were focused on promoting the cultural heritage values of the town. To recognize the determinants of the cultural tourism perspectives in Podkowa Leśna both quantitative and qualitative methods were used. That approach required techniques and instruments specific to the theoretical studies, document analysis as well as to the field research. During the field surveys (interview, participant observation) both quantitative and qualitative data were obtained, of primary the original 
(unpublished) character. The critical study of published materials (as local government reports, plans for new policy and strategy) were the source of secondary data, providing quantitative and qualitative data. For gathering primary data (quantitative and qualitative) interview technique was used, performed in situ, face to face. Semi - structured interviews were carried out with representatives of local authorities (City Council in Podkowa Leśna), NGOs and cultural institutions. This material was also supplemented by the un-structured and informal interviews carried out in situ, face - face with the local community members and tourists during the popular cultural events. These were documented by notes and photographs taken by authors. The participant observations and interview technique were repeated many times, during different cultural events ("The European Heritage Days", "The Open Garden Festivals") in 2010-2015 (Figures 3-4). It is to be underlined that one of the authors had not only the opportunity to participate in the various cultural events, but was the active co-organizer. These personal experiences were the source of many important information concerning the opinions, comments and behaviour of participants the cultural events. To achieve the desired final results and effects and avoid critics of the case study results - the authors tried to design the research work to be consistent with the recommendations of the renowned literature on research in tourism (Cohen, 2007; Finn, 2000; Phillimore, 2009).

\section{Research results}

Three small - scale towns: Podkowa Leśna, Milanówek and Brwinów are located nearby Warsaw. All three are based on the 19c concept of the garden - city, idea developed in UK by Ebenezer Howard. This historic urban planning philosophy is so far still very attractive even today, as providing an exceptional social values, architectural quality of buildings, combined with richness of nature, both public and private gardens. The concept of a garden-city, which promotes the principle of sustainable development and consideration of environment, by many modern scholars and urban planning schools is being considered as a perfect answer and alternative to overcrowded agglomerations, where living conditions are not healthy and social ties are too weak and insufficient to provide and secure inclusion. The uniqueness of the garden - city idea was the base of formal agreement between local governments in Brwinów, Milanówek and Podkowa Leśna. Cultural and sport events were planned as an integral part of the sites promotion.

In Podkowa Leśna, the cultural centre is located in the newly restored historic building of "Casino", located in the urban park. The Centre of Culture and Civic Initiatives together with the Museum of Anna and Jarosław Iwaszkiewicz, St Christopher Church, primary and secondary schools and the Public Library are the main organizers and host institutions for cultural events. It is also worth to underline that many Podkovian residents open their homes to public and allow visiting historic residences and gardens. Moreover some of them organize concerts or literature events (as meetings with writers or musicians), these events have only cameral character. These cultural events are supported by different resources (as EU funds, Local Government in Podkowa Leśna, Ministry of Culture), but the very important collaboration help is provided from the part of inhabitants. At present the city has registered more than twenty NGOs associations and the oldest 
society was founded in 1930: The Friends of Podkowa Leśna. Other societies, focused on the education and culture activities are: The Federation of Podkovians, The Garden of Arts and Sciences Society, The Green Neighbourhood Association, The Association of Singers "Canto Sonoro" and The Foundation Villa Musica. These associations regularly organize various cultural events that are co-financed from the city budget, EU funds, Ministry of Culture funds and some international institution grants (Podkańska, 2009; Urząd Miasta Podkowa Leśna, 2015).

Annually in Podkowa Leśna there are more than 150 cultural events of different scale and character. Some of them are single events, but most are being created as regular project (Figures 2-4). Possibly the most popular are the "Open Gardens Festivals" (“Otwarte Ogrody Festival”), having been organized each summer since 2005, as a three-day cultural event. The theme of events is education in the field of heritage conservation, ecology and sustainable development. It is the feast hosted usually by many private inhabitants in their private gardens, these days being opened to the public. In 2015 the $10^{\text {th }}$ anniversary was celebrated and about 5,000 of visitors were present. What is important, the "Open Gardens Festival" is a showcase for the creative potential of residents and local institutions, local government and NGOs, for good cooperation between private and public stakeholders. It is to be underlined that all events are non-profit, attractions are available free of charge to visitors (Figure 2). The Podkowa Leśna initiative is a good example of effective site promotion and many other small towns near Warsaw (Zalesie Dolne, Komorów, and Józefów) have recently followed the idea.

Another popular cultural event, that is worth to be mentioned in the context of the site successful promotion, is the "European Heritage Days" (Figure 3). Ii is a cultural and educational project sponsored by the Council of Europe, developed since 1992 and aimed to increase the awareness of the local identity and the cultural heritage. Each year there is a new edition with different theme and in 2015 it was "Lost Heritage". In Podkowa Leśna it was celebrated by numerous exhibitions, concerts, presentations, competitions. Although the event is designed only for two days (Saturday-Sunday), in 2015 almost a thousand of participants took part in it. The third important cultural event organized each year in Podkowa Leśna is the "Festival of the Literary and Musical Confrontations" in the Anna and Jarosław Iwaszkiewicz Museum Stawisko. This event has been organized since 2000 and includes a series of concerts, lectures and exhibitions, which lasted from autumn to spring (coordinated with the rhythm of the school year). The annual cycle of events gathers more than a thousand of participants.

The mentioned above cultural events are only example of 150 events organized annually in Podkowa Leśna. The organization of cultural events need to engage both residents (as volunteers) and employees of public institutions. In comparison with other localities, social commitment in Podkowa is at an exceptionally high level; therefore, very valuable are the opinions of residents about the cultural offer in the city. This is confirmed by surveys that have been conducted twice in 2011 and 2014. Comparing these two years one can see the growing satisfaction with cultural offers provision in Podkowa Leśna. Most local community members and visitors were satisfied and very satisfied of the opportunity they have to participate (as a spectator) in cultural events offered by the city (75.2\%), the possibility of active participation was rated as good and very good by 
$67.4 \%$ responders. Activities arranged by the cultural institutions were highly approved by $65.9 \%$ of responders (Mantey, 2015). This high rating of the cultural offer, approval declared by people, is extremely important, as they co-create the image (brand) of the site and region. Numerous scholars underline that so-called "word of mouth" is one of the most effective methods of promotion and reaching out for new customers. Satisfactory experience, appreciating opinions about the high level of cultural offer in Podkowa Leśna could possibly motivate Warsaw inhabitants to choose this site for their "weekend break" (Figures 2-4). The strong potential for a short stay visits and tourist development in Podkowa Leśna (weekend breaks) is determined by the following factors (Figure 1):

- natural resources and cultural heritage values,

- accommodation and catering offer,

- local transport (WKD train service to Warsaw),

- very special tradition of site, unique hospitality and charming atmosphere,

- high aesthetic values of garden - city layout, historic and modern villas architecture,

- high quality of environment components,

- numerous tourist routs, cultural events,

- information and innovative tourist products.

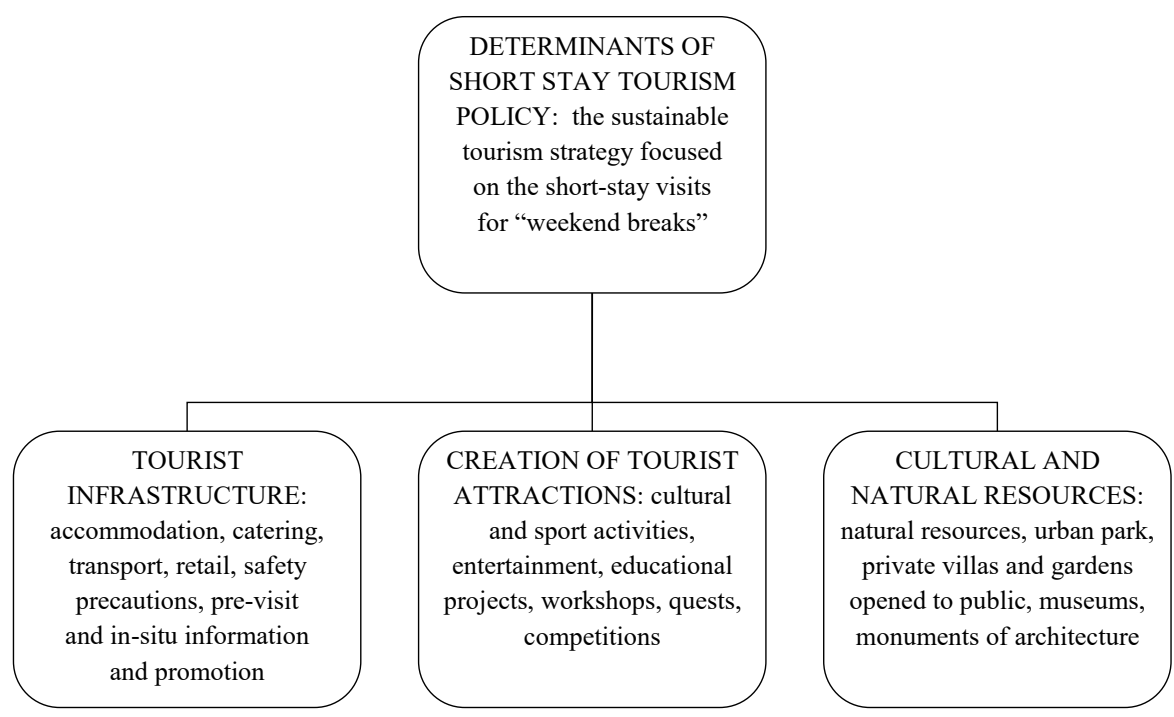

Figure 1. Podkowa Leśna possible strategy concept of tourism sustainable development

(short-stay visits, "weekend breaks" concept) - the main determinants identification

Source: The presented material is the result of research conducted on the base of the grant issued by the Ministry of Higher Education and Sciences (ds-114 and ds-144 AWF), carried out by the authors at the Joseph Pilsudski Academy of Physical Education in Warsaw, Poland (2012-2015).

The non answered question remains, if these cultural events in future - in a broad sense of tangible and intangible forms - could, be also successful within the same concept. It is possible 
that the rapidly changing world and society will require re-formulating the strategy to continue the successful promotion, sustainable development, social and cultural harmony and economic growth. Another research study theme to be considered in future is the question of the limits of tourism development in Podkowa Leśna, without endanger its uniqueness, the high cultural, natural values and very special social atmosphere, tradition and host community interconnections. It is already a well-known fact, that the consideration of the tourism impact on the environment and host community should be a vital part of the local and regional planning strategies (Hall, 2000, OECD, 2009, UNESCO, 2009). There is a wide range of factors to be recognised, many requiring subjective, not only objective analysis. As it is planned, the key factors to identified main determinants should be: the quality of environment, the heritage protection, the aesthetic values, the safety factors, the society identity, the local community approach towards tourist growth, the cultural and other forms of tourism environment impact. The authors are aware of the fact, that this approach will involve interpreting needs, as some elements of resource index might require a subjective judgment (as for example aesthetic values). However the methodology design for the new research project is now in progress.

Table 1. Main stakeholders actively collaborating in creating the cultural policy in Podkowa Leśna (selected organizers of the most popular projects in 2010 and 2013)

\begin{tabular}{lccc}
\hline Main stakeholders & $\begin{array}{c}\text { Centre of Culture } \\
\text { and Civic Initiative } \\
\text { in Podkowa Leśna }\end{array}$ & $\begin{array}{c}\text { Municipal Library } \\
\text { in Podkowa Leśna }\end{array}$ & $\begin{array}{c}\text { Museum of } \\
\text { Anna i Jarosław Iwaszkiewicz } \\
\text { in Stawisko - Podkowa Leśna }\end{array}$ \\
\hline $\begin{array}{l}\text { Events organized in 2010 } \\
\text { (number of participant) }\end{array}$ & 118 events (11,500 participants) & 7 events (700 participants) & $\begin{array}{c}25 \text { events (number of participants } \\
\text { not recorded) }\end{array}$ \\
\hline $\begin{array}{l}\text { Events organized in 2013 } \\
\text { (number of participants) }\end{array}$ & 127 events (17,750 participants) & $\begin{array}{c}9 \text { events (number of participants } \\
\text { not recorded) }\end{array}$ & $\begin{array}{c}50 \text { events (number of participants } \\
\text { not recorded) }\end{array}$ \\
\hline
\end{tabular}

Source: The presented material is the result of research conducted on the base of the grant issued by the Ministry of Higher Education and Sciences (ds-114 and ds-144 AWF), carried out by the authors at the Joseph Pilsudski Academy of Physical Education in Warsaw, Poland (2012-2015). Data based the reports of main cultural institutions operating in Podkowa Leśna (2010-2013).

\section{Conclusions}

In the recent years, the idea of cultural events as a locomotive of tourist development is gaining greater numbers of followers. Several scholars highlighted the culture, education, innovation and integrated approach as key factors to enhance the long - term competitiveness of the reception area. In many European countries the organized on small - scale cultural and sport events are popular as tourist attractions. The Garden Tri-Cities initiative (Brwinów, Milanówek and Podkowa Leśna) was designed not only to promote the cities themselves and strengthen their position in relations with other regional actors, but also to promote the idea of social and space uniqueness. The visible results of this fruitful cooperation are popular cultural, sporting and educational events, described on the example of Podkowa Leśna. These local government and local community activities are 


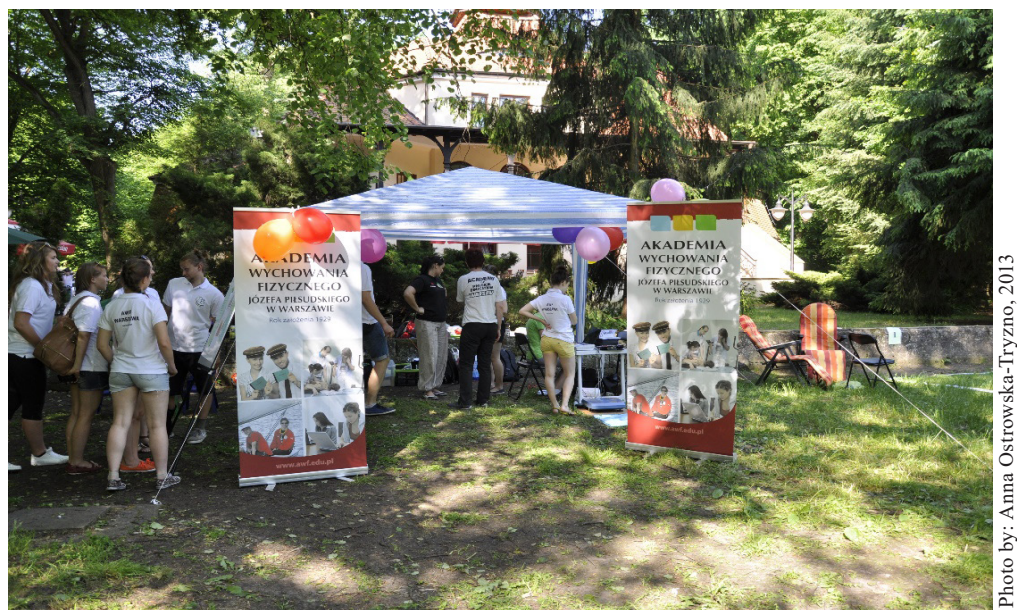

Figure 2. Podkowa Leśna. Example of sustainable development of the cultural tourism in the small town (short-stay visits, "weekend breaks" concept) - the "Podkowianska Kilometer Event" ("Pdkovian Ten Event"), 2015

Source: The presented material is the result of research conducted on the base of the grant issued by the Ministry of Higher Education and Sciences (ds-114 and ds-144 AWF), carried out by the authors at the Joseph Pilsudski Academy of Physical Education in Warsaw, Poland (2012-2015).

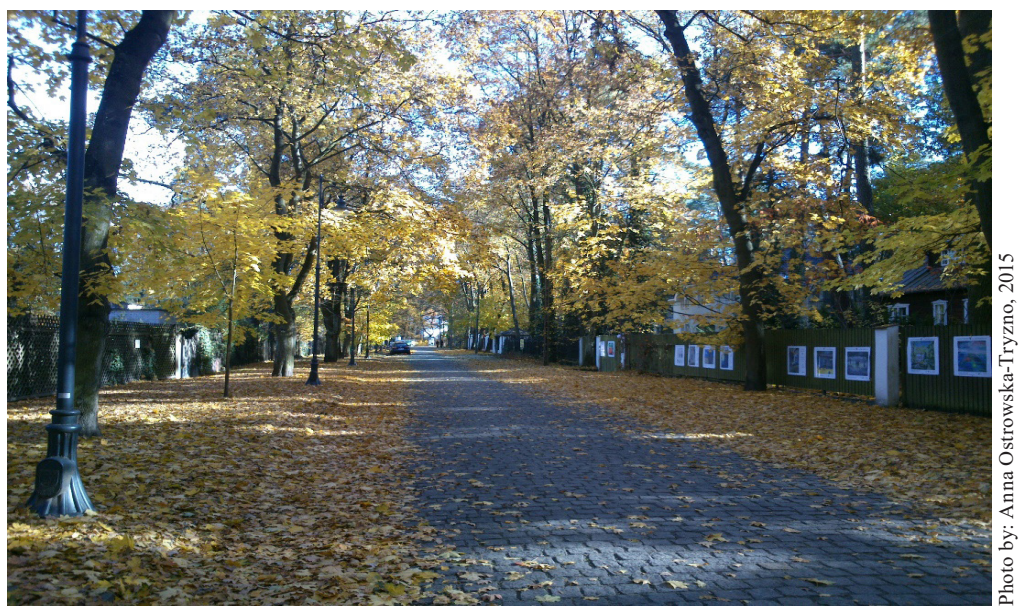

Figure 3. Podkowa Leśna. Example of sustainable development of the cultural tourism in the small town (short-stay visits, "weekend breaks" concept) - the Lilpopa Street Open Air Exhibition (European Heritage Days, 2015)

Source: The presented material is the result of research conducted on the base of the grant issued by the Ministry of Higher Education and Sciences (ds-114 and ds-144 AWF), carried out by the authors at the Joseph Pilsudski Academy of Physical Education in Warsaw, Poland (2012-2015). 


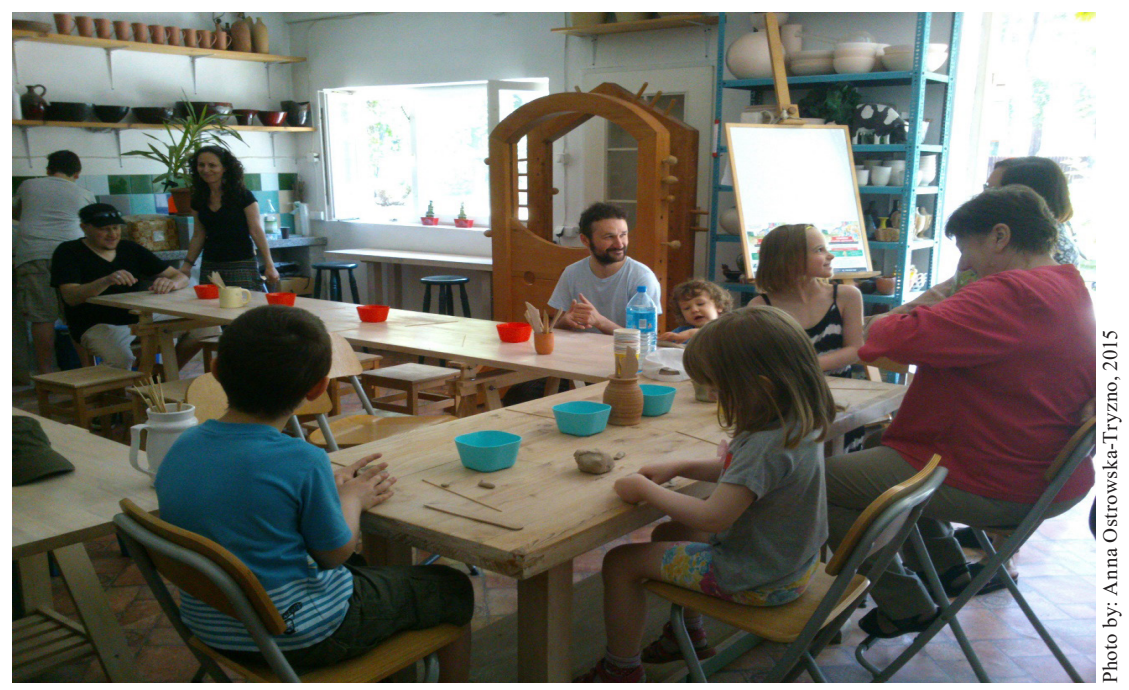

Figure 4. Podkowa Leśna. Example of sustainable development of the cultural tourism in the small town (shortstay visits, "weekend breaks" concept) - the Open Gardens Festival, traditional pottery workshop, 2015

Source: The presented material is the result of research conducted on the base of the grant issued by the Ministry of Higher Education and Sciences (ds-114 and ds-144 AWF), carried out by the authors at the Joseph Pilsudski Academy of Physical Education in Warsaw, Poland (2012-2015).

supported by the city authorities, cultural institutions, NGOs and above all - local community members. Thanks to the extremely popular cultural events, such as: "The Open Gardens Festival" and "The European Heritage Days", many visitors are able to know more about the garden-city idea and the region (Figures 3-4).

In Podkowa Leśna the tourist offer is not very rich, but accommodation and catering services allow spending there a pleasant weekend. It is true, that not many tourists stay overnight at the site (as it is very easy to come back to Warsaw, due to the well-developed public transport service). However many visitors come back in the next weekends to take advantage of cultural and natural resources they have learnt about, to walk along tourist routs, cycle, ride a horse, visit one of few museums located there and to dine in the local charming cafes or restaurants. It seems to be a highly popular "weekend break" for Warsaw inhabitants, appreciating this natural and peaceful site, unspoiled and relaxing atmosphere, enriched by cultural heritage, cultural and sport events. However, the further research study question remains about the rational limits of future tourism development in Podkowa Leśna, without endanger its uniqueness, the high cultural and natural values, very special social atmosphere, tradition and social interconnections.

Undeniable the future of tourist product developed by the "The Garden Tri-Cities" and its perspective depends highly on governance on the local level, action plan to support sustainable and competitive tourism. The presented examples of cultural events illustrate very clearly the role of culture in creating distinctiveness for tourism in Podkowa Leśna and show how supportive 
strategies between tourism and culture can make a difference. The authors hope that the presented outcomes of the research survey could help to understand better the tourism perspectives in Mazovia Region, especially in the small towns and villages, where there are not, so far, widely acclaimed tourist attractions and which face the challenge to create their tourist product brand out from scratches.

\section{Acknowledgments}

The presented material is the result of research conducted on the base of two grants offered by the Ministry of Higher Education and Sciences (ds-114 AWF and ds-144 AWF), carried out by the authors at the Joseph Pilsudski Academy of Physical Education in Warsaw (2012-2015). Some of the outcomes were presented in September 2015 at WSTIJO University Conference in Warsaw (in Polish).

\section{References}

Cohen, L., Manion, L., Morrison, K. (2008). Research Methods in Education. New York: Routledge.

Dallen, J.T., Boyd, S.W. (2003). Heritage tourism. Harlow: Prentice Hall.

Finn, M., Elliott-White, M., Walton, M. (2000). Tourism \& Leisure Research Methods. Data Collection, Analysis and Interpretation. Harlow: Longman.

Gold, J.R., Ward, S.V. (1994). Place promotion: the use of publicity and marketing to sell towns and regions. Chichester: John Wiley \& Sons Ltd.

Goodall, B., Ashworth, G. (2013). The Promotion of Destination Regions. New York: Routledge.

Hall, D. (1999). Destination branding, niche marketing and national projection in Central and Eastern Europe. Journal of Vacation Marketing, 5 (3), 227-237. DOI: 10.1177/135676679900500303.

Hall, M.C. (2000). Tourism Planning. Policies, Process and Relationship. Harlow: Prentice Hall.

Inskeep, E. (1994). National and regional tourism planning methodologies and case studies. World Tourism Organization. New York: Routledge.

Mantey, D. (2014). Opinie mieszkańców Gminy Brwinów i Podkowa Leśna nt. warunków życia i jakości usług publicznych. Raport z badań. Brwinów: UM Podkowa Leśna, UG Brwinów, Stowarzyszenie LGD Zielone Sąsiedztwo.

Organisation for Economic Co-operation and Development, Tourism Committee (2009). The Impact of Culture on Tourism Report, OECD Tourism Papers Series, Paris.

Page, S.J., Hall, S.C. (2003). Managing urban tourism. Harlow: Prentice Hall.

Panasiuk, A. (ed.) (2013). Marketing $w$ turystyce i rekreacji. Warszawa: PWN.

Phillimore, J., Goodson, L. (2009). Qualitative Research in Tourism. London-New York: Routledge.

Podkańska, B. (2009). Strategia rozwoju turystyki gmin Brwinów i Podkowa Leśna na lata 2010-2015. Podkowa Leśna: Stowarzyszenie LGD Zielone Sąsiedztwo.

Richards, G. (2001). Cultural Attractions and European Tourism. New York: CABI Publishing.

Sigala, M., Leslie, D. (2006). Cultural tourism. London: Elsevier.

Smith, M. (2009). Issues in Cultural Tourism Studies. New York: Routledge.

Thomas, R. (2014). Managing Regional Tourism. Leeds: Northern Books.

United Nations Educational, Scientific and Cultural Organization (UNESCO) (2009) Plan of Action on Tourism management in Heritage Cities. Paris: UNESCO Office in Paris. 
Urząd Miasta Podkowa Leśna (2015). Sprawozdanie z realizacji programu wspótpracy Miasta Podkowy Leśnej z organizacjami pozarządowymi i podmiotami prowadzacymi działalność pożytku publicznego na rok 2012, $2013,2014$. Podkowa Leśna: Urząd Miasta Podkowa Leśna.

Williams, S. (2003). Tourism and Recreation. Harlow: Prentice Hall.

\section{PLANOWANIE KRÓTKICH POBYTÓW WEEKENDOWYCH I ŚWIĄTECZNYCH OPARTYCH O KULTUROWE, PRZYRODNICZE I SPOŁECZNE WALORY} MAŁYCH MIAST

SŁOWA KLUCZOWE STRESZCZENIE turystyka kulturowa, krótkie pobyty, turystyka zrównoważona, małe miasta, promocja

Tematem artykułu jest zaprezentowanie metod kreacji atrakcyjnego produktu turystycznego małych miast, przy wykorzystani ich specyfiki kulturowej i społecznej oraz wartości przyrodniczych. W szczególności w te potencjały, jak się okazuje, doskonale wpisuje się turystyka kulturowa, krótkie pobyty świąteczne i weekendowe, nie wymagające skomplikowanej i kosztownej infrastruktury. W artykule przestawiono teoretyczne podstawy rozwoju turystyki kulturowej, metod jej marketingu w małych ośrodkach oraz znaczące efekty jakie niesie skoordynowana i konsekwentna współpraca samorządu terytorialnego z instytucjami pozarządowymi. Przykładem dobrych praktyk w tym zakresie są działania podejmowane przez samorząd oraz organizacje pozarządowe w Podkowie Leśnej pod Warszawą.

Jako pytanie otwarte autorzy tekstu pozostawiają rozważanie jakie powinny być limity rozwoju turystyki w małym mieście, tak aby zapewnić rozwój zrównoważony i nie zagrozić walorom kulturowym, społecznym i przyrodniczym oraz unikalnej atmosferze miejsca. 